\title{
Free Speech and Impermissible Motive in the Dismissal of Public Employees
}

For public employees throughout the United States, the protection of the First Amendment is restricted and inadequately enforced. ${ }^{1}$ While the citizenry is entitled to engage in wide-open debate, ${ }^{2}$ public employees must confine their speech within narrower bounds. ${ }^{3}$ Even when their speech is nominally protected, public employees are vulnerable to covert sanctions. ${ }^{4}$ If an employee is removed for exercising his First Amendment rights and sues for reinstatement, ${ }^{5}$ the employer can defeat the action by showing that he would have removed the employee

1. This Note examines only the First Amendment rights of public employees because private employees do not hold First Amendment rights against their employers unless there is state action. See Holodnak v. Arco Corp., 514 F.2d 285, 288-89 (2d Cir.), cert. denied, 423 U.S. 892 (1975) (finding state action in dismissal of employee for exercising First Amendment rights because of "symbiotic relationship" between government and private employer). State and federal employees do hold First Amendment rights against their employers. See Pickering v. Board of Educ., 391 U.S. 563, 568 (1968).

2. New York Times Co. v. Sullivan, 376 U.S. 254, 270 (1964).

3. Pickering v. Board of Educ., 391 U.S. 563, 568 (1968) (establishing special balancing test for employees' speech); see pp. 381-82 and note 4.5 infra (discussing Pickering test); cf. Givhan v. Western Line Consol. School Dist., 439 U.S. 410, 415 n.4 (1979) (employee's private expression may "bring additional factors to the Pickering calculus"). But see Pilkington v. Bevilacqua, 439 F. Supp. 465, $478-79$ n.11 (D.R.I. 1977), aff'd, 590 F.2d 386 (Ist Cir. 1979) (suggesting employee's right qua employee "to participate and express his opinions in his place of work without fear of reprisal").

Public-employee free speech issues commonly arise in the context of public elementary and secondary schools. The tension over teachers' expression is great because the schools are considered both marketplaces of ideas, see Tinker v. Des Moines Independent Community School Dist., 393 U.S. 503, 512 (1969), and places in which teachers shape "the attitude of young minds towards the society in which they live," Adler v. Board of Educ., 342 U.S. 485, 493 (1952). See generally Note, Developments in the Law-Academic Freedom, 81 Harv. L. Rev. 1045 (1968) (surveying legal protection of students' and teachers' rights).

4. The absence of open procedures for reaching personnel decisions makes it difficult to ascertain the motivation behind such decisions. See Mazaleski v. Treusdell, 562 F.2d 701, 715 (D.C. Cir. 1977). The Supreme Court has recognized that "the threat of dismissal from public employment is . . . a potent means of inhibiting speech." Pickering v. Board of Educ., 391 U.S. 563, 574 (1968). See generally K. Davis, DiscretionarY Justice 111-16 (1969) (discussing openness as protection against arbitrariness).

5. Since the elimination of the amount in controversy requirement in suits against the United States, such suits may be brought against federal employers under 28 U.S.C. $\S 1331$ (a) (1976). See Porter v. Califano, 592 F.2d 770, 771 n.1 (5th Cir. 1979). Such suits may be brought against state employers under 42 U.S.C. $\$ 1983$ (1976). Equitable relief is sought because in most cases state officers will be shielded by personal immunity from damage actions when acting in good faith within their authority. McCormack, Federalism and Section 1983: Limitations on Judicial Enforcement of Constitutional Protections, Part $I, 60$ VA. L. REv. 1, 59 (1974). Reinstatement remedies depart from the old notion that equity will enforce employment contracts only negatively and not specifically. Id. at 60; see J. Pomeroy \& J. McMann, Specific Performance of Contracts 75-76 (3d ed. 1926). 
even had the employee not engaged in the protected activity. ${ }^{6}$ The employee can prevail only if the court finds that, but for the protected activity, the employee would not have been removed. ${ }^{7}$ This combination of substantive limitations, covert sanctions, and administrative unaccountability effectively stifles public employees. ${ }^{8}$

This Note argues that covert abridgments of protected speech should be attacked by changing the standard of proof in reinstatement suits. ${ }^{9}$ Only a replacement of the current but-for test with one that asks whether protected activity was simply a substantial cause of the decision to remove the employee can lead to greater administrative accountability. After describing the procedural rights and First Amendment rights of public employees, the Note examines the defects of the but-for test. The Note then proposes and justifies the alternative substantial-cause test. ${ }^{10}$

\section{The Rights of Public Employees}

Although the constitutional rights of public employees have expanded over the last thirty years, ${ }^{11}$ courts remain deferential to per-

6. Givhan v. Western Line Consol. School Dist., 439 U.S. 410, 416-17 (1979); Mt. Healthy City School Dist. Bd. of Educ. v. Doyle, 429 U.S. 274, 287 (1977); see pp. 383-84 infra.

7. Although the Supreme Court adopted this rule in Mt. Healthy City School Dist. Bd. of Educ. v. Doyle, 429 U.S. 274, 287 (1977), it first described the test in terms of "but-for" causation in Givhan v. Western Line Consol. School Dist., 439 U.S. 410, 417 (1979).

8. See Van Alstyne, Cracks in "The New Property": Adjudicative Due Process in the Administrative State, 62 CoRnell L. Rev. 445, 450 n.13 (1977) (Mt. Healthy test characterized as "Catch 22" and "confession and avoidance").

9. The appropriateness of current substantive limitations on employee speech is beyond the scope of this Note. Compare Pickering v. Board of Educ., 391 U.S. 563, 569-72 (1968) (establishing limits on employee speech) with Adler v. Board of Educ., 342 U.S. 485, 508 (1952) (Douglas, J., dissenting) (rejecting any distinction between citizen's and public employee's speech rights).

10. Although this Note focuses on removals that involve the exercise of First Amendment rights, the $M$ t. Healthy test, see pp. 383-84 infra, applying a but-for standard, also has been applied to removals or refusals to hire for other impermissible reasons, see, e.g., East Tex. Motor Freight Sys., Inc. v. Rodriguez, 431 U.S. 395, 404 n.9 (1977) (job applicants' Title VII claim of racial discrimination); NLRB v. Eastern Smelting and Refining Corp., 598 F.2d 666, 671 (1st Cir. 1979) (test of discriminatory discharge under National Labor Relations Act). The test also has been invoked in contexts other than government employment. See, e.g., Village of Arlington Heights v. Metropolitan Hous. Dev. Corp., 429 U.S. 252, $270-71 \mathrm{n} .21$ (1977) (racially discriminatory zoning); Winters v. Lavine, 574 F.2d 46, 64 (2d Cir. 1978) (denial of Medicaid benefits); Comment, Proof of Racially Discriminatory Purpose under the Equal Protection Clause: Washington v. Davis, Arlington Heights, Mt. Healthy, and Williamsburgh, 12 HARv. C.R.-C.L. L. REv. 725, 745-52 (1977) (Mt. Healthy indicates "strict scrutiny" will not be applied to mixed motives decisions).

11. In Keyishian v. Board of Regents, 385 U.S. 589 (1967), the Supreme Court expressly rejected the premise it found embodied in Adler v. Board of Educ., 342 U.S. 485 (1952), namely, that public employment "may be conditioned upon the surrender of constitutional rights which could not be abridged by direct government action." 385 U.S. at 605 .

For many years, the prevailing philosophy was that expressed by Mr. Justice Holmes in 
sonnel decisions of local administrators. ${ }^{12}$ Such deference to discretionary administrative procedures undermines the First Amendment rights of public employees.

\section{A. Procedural Rights}

Public employees who are removed from jobs have a minimum of procedural rights. An administrative hearing is required under the due process clause only if the removal implicates the employee's property or liberty interests. ${ }^{13} \mathrm{~A}$ nontenured or probationary public employee is not entitled to a statement of reasons for his removal; ${ }^{14}$ he may be removed for any reason but an unconstitutional one-or for no reason at all. ${ }^{15}$

An employee's property interest is derived from existing rules or understandings that stem from a source outside the Constitution, such as statutes or regulations. ${ }^{16}$ Although the Supreme Court has not settled whether the entitlement may limit its procedural concomitants, ${ }^{17}$

McAuliffe v. Mayor of New Bedford, 155 Mass. 216, 29 N.E. 517 (1892):

The petitioner may have a constitutional right to talk politics, but he has no constitutional right to be a policeman. There are few employments for hire in which the servant does not agree to suspend his constitutional right of free speech, as well as of idleness, by the implied terms of his contract. The servant cannot complain, as he takes the employment on the terms which are offered him.

Id. at 220,29 N.E. at $517-18$.

The case that marked the beginning of the Supreme Court's more protective attitude toward public employees' First Amendment rights was decided shortly after AdlerWieman v. Updegraff, 344 U.S. 183 (1952) (refusing to enjoin payment to employees who had not subscribed to loyalty oath). See generally Van Alstyne, The Demise of the RightPrivilege Distinction in Constitutional Law, 81 HARv. L. Rev. 1439 (1968) (reviewing Supreme Court techniques for avoiding harsh consequences of characterizing government benefit as "privilege").

12. Note, A Constitutional Interest in Public Employment: The Last Hurrah?-Bishop v. Wood, 26 DePaul L. Rev. 631, 649 (1977).

13. Board of Regents v. Roth, 408 U.S. 564, 569 (1972); see Bishop v. Wood, 426 U.S. 341 (1976) (policeman's termination implicated neither property nor liberty interest).

14. Board of Regents v. Roth, 408 U.S. 564, 569 (1972); see Cafeteria \& Restaurant Workers Union, Local 473 v. McElroy, 367 U.S. 886, $896-97$ (1961) (absent statutory limitation, government employer has broad latitude to hire and fire).

15. See Mt. Healthy City School Dist. Bd. of Educ. v. Doyle, 429 U.S. 274, 283 (1977) (nontenured employee may be discharged "for no reason whatever").

16. Perry v. Sindermann, 408 U.S. 593, 601 (1972); Board of Regents v. Roth, 408 U.S. 564,577 (1972).

17. In Arnett v. Kennedy, 416 U.S. 134 (1974), the three-justice plurality stated that the property interest was conditioned by "procedural limitations which had accompanied the grant of that interest." Id. at 155 (Rehnquist, Stevens, JJ., \& Burger, C.J.). The other six justices expressly rejected that view. $I d$. at 166-67 (Powell, Blackmun, JJ., concurring); id. at 177-78 (White, J., dissenting); id. at 211 (Marshall, Brennan, Douglas, JJ., dissenting). In Bishop v. Wood, 426 U.S. 341 (1976), the five-justice majority held that under the law of the state a "permanent" employee did not have a property right and could therefore be constitutionally removed at will. $I d$. at $345 \&$ n.8. The four dissenters claimed that the Bishop majority had thereby adopted the "bitter with the sweet" position advocated by the plurality in Arnett. Id. at 357-61. 
it has made clear that rudimentary procedures will usually satisfy an employee's hearing rights. ${ }^{18}$

Removal of an employee for derogatory or stigmatizing reasons that he alleges are false implicates his liberty interests and entitles him to an administrative hearing to clear his name. ${ }^{19}$ Yet the fact of nonretention $^{20}$ and the communication to an employee of an erroneous reason for his removal ${ }^{21}$ have been held not to infringe liberty interests. The Court has held that the Constitution does not provide federal judicial review as a protection against administrative errors. ${ }^{22}$

\section{B. First Amendment Rights}

Public employees who criticize either the specific institution with which they are associated ${ }^{23}$ or the government more generally ${ }^{24}$ are vulnerable to employment reprisals. Such criticism may annoy or threaten an employee's superiors, leading to reprisals that can range from refusal to hire ${ }^{25}$ to outright dismissal, ${ }^{26}$ including such intermediate steps as suspension, ${ }^{27}$ nonrenewal, ${ }^{28}$ transfer, ${ }^{29}$ and the denial of

18. See, e.g., Arnett v. Kennedy, 416 U.S. 134, 155-56 n.21 (1974) (supervisor who charged employee with slandering him may rule on employee's termination).

19. Codd v. Velger, 429 U.S. 624, 627 (1977) (per curiam); Board of Regents v. Roth, 408 U.S. 564, 573 n.12 (1972).

20. See Bishop v. Wood, 426 U.S. 341, 348 (1976) (discharge of employee whose position was "terminable at the will of the employer"); Board of Regents v. Roth, 408 U.S. 564, 575 (1972) (nonrenewal of untenured professor).

21. Bishop v. Wood, 426 U.S. 341,349 \& $n .13$ (1976) (providing mistaken reason or deliberate lie does not infringe protected liberty interest).

22. Id. at 349-50 (accepting "harsh fact that numerous individual mistakes are inevitable in the day-to-day administration of our affairs").

23. See, e.g., Fitzgerald v. Seamans, 384 F. Supp. 688, 690 (D.D.C. 1974) (employee testified before congressional committee on \$2-billion cost overrun on aircraft project). See generally Conference on Professional Responsibility, Whistle Blowing (R. Nader, P. Petkas, \& K. Blackwell eds. 1972) (examples of such criticism brought by government and corporate employees) [hereinafter cited as WHistLe BLowing].

24. See, e.g., Stolberg v. Members of Bd. of Trustees, 474 F.2d 485, 487 (2d Cir. 1973) (professor sent letter to fellow faculty members inviting them to Vietnam war protest).

25. See, e.g., Franklin v. Atkins, 562 F.2d 1188 (10th Cir. 1977), cert. denied, 435 U.S. 994 (1978) (professor).

26. See, e.g., Choudhry v. Jenkins, 559 F.2d 1085 (7th Cir.), cert. denied, 434 U.S. 997 (1977) (probationary correctional officer); Shaw v. Board of Trustees, 549 F.2d 929 (4th Cir. 1976) (one tenured professor, one professor under continuing appointment).

27. See, e.g., Porter v. Califano, 592 F.2d 770 (5th Cir. 1979) (30-day suspension of federally employed clerk); Kannisto v. City and County of San Francisco, 541 F.2d 841 (9th Cir. 1976), cert. denied, 430 U.S. 931 (1977) (15-day suspension of police lieutenant).

28. See, e.g., Board of Regents v. Roth, 408 U.S. 564 (1972) (assistant professor); Ofsevit v. Trustees of Cal. State Univ. and Colleges, 21 Cal. $3 d$ 763, 582 P.2d 88, 148 Cal. Rptr. 1 (1978) (en banc) (university lecturer).

29. See, e.g., Simpson v. Weeks, 570 F.2d 240 (8th Cir. 1978), cert. denied, 99 S. Ct. 3101 (1979) (policeman transferred to city jail); Alicea Rosado v. Garcia Santiago, 562 F.2d 114 (1st Cir. 1977) (social worker transferred to position with same rating but less prestige and responsibility and more commuting time). 
promotion $^{30}$ or tenure. ${ }^{31}$ At times the employer may remove the employee explicitly on the ground that the employee's criticism impairs the efficiency of the public service. ${ }^{32}$ More commonly, reprisals will be covert: the employee will be removed allegedly on other grounds, stated or unstated..$^{33}$ Usually these other grounds actually exist, but it will be unclear whether the employer would have acted on them had the employee not spoken out. ${ }^{34}$

Public employee speech implicates First Amendment values not because it tests the outer substantive limits of protected speech $^{35}$ but because it tests the nature of the protection afforded First Amendment rights. ${ }^{36}$ In contrast to speech that has provoked such dramatic and explicit sanctions as prior restraint ${ }^{37}$ and criminal prosecution, ${ }^{38}$ speech by public employees tests judicial willingness to ferret out covert abridgments of common political speech. ${ }^{30}$ Such protection is im-

30. See, e.g., Bickel v. Burkhart, 462 F. Supp. 682 (N.D. Tex. 1978) (fireman); DeLuca v. Sullivan, 450 F. Supp. 736 (D. Mass. 1977) (policemen).

31. See, e.g., Mt. Healthy City School Dist. Bd. of Educ. v. Doyle, 429 U.S. 274 (1977) (school teacher); Megill v. Board of Regents, 541 F.2d 1073 (5th Cir. 1976) (university professor).

32. See Pickering v. Board of Educ., 391 U.S. 563, 568 (1968) (recognizing that public employees' speech can impair efficient government services).

33. See Mazaleski v. Treusdell, 562 F.2d 701, 715 (D.C. Cir. 1977) (noting that “actual grounds for dismissal . . may not be readily ascertainable, and almost always are vigorously contested by the litigants").

34. See Mt. Healthy City School Dist. Bd. of Educ. v. Doyle, 429 U.S. 274, 285 (1977) (distinguishing fact that employer "could have" removed employee from question of whether it "would have" removed him).

35. See Wellington, On Freedom of Expression, 88 YALE L.J. 1105, 1131-33 (1979) (examining advocacy of genocide).

36. See Pickering v. Board of Educ., 391 U.S. 563, 574 (1968) (threat of dismissal from public employment a potent means of inhibiting speech).

37. See, e.g., New York Times Co. v. United States, 403 U.S. 713 (1971) (vacating injunction prohibiting publication of Pentagon Papers); United States v. The Progressive, Inc., 467 F. Supp. 990 (W.D. Wis. 1979) (enjoining publication of article on construction of hydrogen bomb).

38. See, e.g., Hess v. Indiana, 414 U.S. 105 (1973) (reversing conviction for incitement during campus antiwar demonstration); Brandenburg v. Ohio, 395 U.S. 444 (1969) (reversing conviction of $\mathrm{Ku} \mathrm{KIux}$ Klan leader for advocating violence at rally).

39. As Professor Emerson has noted, weaker procedural safeguards may make an administrative system "a much tighter, more pervading form of restriction" than a criminal system, and the low visibility of administrative decisions makes the "imagined impact of the restriction ... the most repressive feature of all." T. EMERson, THE SYsteM of FreEDOM OF EXPRESSION 163 (1970).

Protection of the kind of speech involved in these cases would be unproblematic were it not for the employment relationship. Typically it involves such conduct as informing the news media of matters of local significance, see, e.g., Pickering v. Board of Educ., 391 U.S. 563 (1968) (teacher wrote local newspaper criticizing school board's handling of revenue proposals), communicating to superiors or fellow employees within the institution, see, e.g., Alicea Rosado v. Garcia Santiago, 562 F.2d 114 (Ist Cir. 1977) (social worker informed superiors of administrative irregularities in food stamp program), or advocating 
portant because it is in these innumerable, minor daily occasions of political speech that freedom of speech flourishes in a society. ${ }^{40}$

The Supreme Court has granted qualified protection to speech by public employees. In Pickering v. Board of Education, ${ }^{41}$ the Court rejected the position that citizens may be compelled to relinquish First Amendment rights in order to obtain public employment. ${ }^{42}$ Yet the Court cautioned that "the State has interests as an employer in regulating the speech of its employees that differ significantly from those it possesses in connection with regulation of the speech of the citizenry in general." 43 The employee's free speech interest must be balanced

the rights of others, typically minors, see, e.g., Bernasconi v. Tempe Elementary School Dist. No. 3, 548 F.2d 857, 859 (9th Cir.), cert. denied, 434 U.S. 825 (1977) (school counsellor advised parents of children placed in classes for mentally retarded to consult legal aid society).

40. See Pickering v. Board of Educ., 391 U.S. 563, 572 (1968) (recognizing that teachers are especially important members of the public with respect to school issues); A. BICKEL, The Morality of Consent 62 (1975) (recognizing essential First Amendment interest in "[d]iscussion, the exchange of views, the ventilation of desires and demands"); WHISTLE BLowiNG, supra note 23, at 10 (noting importance of whistleblowers as internal check on governmental behavior).

Congress recently provided federal employees with statutory protection against reprisals for whistleblowing. Civil Service Reform Act of 1978, Pub. L. No. 95-454, $\$ 2301$ (b)(9), 92 Stat. 1114 (1978) (codified at 5 U.S.C.A. $\$ 2301(b)(9)$ (West 1979)). The same act created a Special Counsel with authority to preserve the anonymity of whistleblowers. Id. $\$ 1206$ (b)(1), 92 Stat. 1125 (codified at 5 U.S.C.A. $\$ 1206$ (b)(I) (West 1979)).

41. 391 U.S. 563 (1968).

42. Id. at 568 .

43. Id. The weight given the state interest in regulating its employees' First Amendment rights varies with the nature of the job. Nonpolicymaking employees can be arrayed on a spectrum, from university professors at one end to policemen at the other. State inhibition of academic freedom is strongly disfavored. See Wieman v. Updegraff, 344 U.S. 183, 195 (1952) (Frankfurter, J., concurring). In polar contrast is the discipline demanded of, and freedom correspondingly denied to, policemen. See, e.g., Gasparinetti v. Kerr, 568 F.2d 311, 321 (3d Cir. 1977) (Rosenn, J., dissenting in part), cert. denied, 436 U.S. 903 (1978) (police are "para-military force"); Kannisto v. City and County of San Francisco, 541 F.2d 841, 843 (9th Cir. 1976), cert. denied, 430 U.S. 931 (1977) (emphasizing police department's interest in discipline, esprit de corps, and uniformity).

Policymakers occupy a special position and may be dismissed without regard to the First Amendment. See Mitchell v. King, 537 F.2d 385, 391 (10th Cir. 1976) (upholding governor's removal of appointee for expressions made "in contravention of the policy goals of the governor"); cf. Elrod v. Burns, 427 U.S. 347, 367.68 (1976) (plurality opinion) (differences between policymaking and nonpolicymaking government employees with respect to patronage dismissals).

The speech rights of CIA employees are even more restricted than those of policymakers. Contractual provisions giving the CIA the right to restrain even former employees from publishing information derived from classified sources have been upheld against First Amendment challenges. United States v. Snepp, 595 F.2d 926, 932 (4th Cir.), petition for cert. filed, 48 U.S.L.W. 3131 (U.S. Aug. 17, 1979) (No. 79-265) (agreement giving CIA right to withhold consent to publication of classified information not in public domain, not violative of First Amendment); Alfred A. Knopf, Inc. v. Colby, 509 F.2d 1362, 1370 (4th Cir.), cert. denied, 421 U.S. 992 (1975) (CIA employee contractually relinquished First Amendment rights with respect to classifiable information). 
against the state's interest in providing efficient public services. ${ }^{44}$ In determining whether the employee's speech is protected, courts are to consider both the nature of the speech and the nature of the employment relation. ${ }^{45}$

Although the Pickering calculus integrates the substantive rights of employer and employee, the absence or rudimentary nature of procedural constraints on personnel decisions weakens the employee's substantive rights. Some covert or inadvertent abridgment of protected speech is an inevitable cost of not imposing rigid procedural constraints on administrative decisionmaking. ${ }^{46}$ That cost includes both the injury suffered by the removed employee and the consequential chilling effect on the exercise of First Amendment rights by other employees. The cost can be minimized through judicial reinstatement of employees removed, at least in substantial part, for exercising their First Amendment rights. The current test for determining when an employee is entitled to reinstatement fails to take into account the effect of a highly

44. Pickering v. Board of Educ., 391 U.S. 563, 568 (1968). Mr. Justice Douglas has questioned the uncritical use of the justification of efficiency for limiting employees' rights. He suggests that many administrators may be more concerned with such internal institutional values as a "pleasant manner, promotion of staff harmony, servility to the cadre, and promptness, civility, and submissiveness" than with efficient performance. Arnett v. Kennedy, 416 U.S. 134, 205 (1974) (Douglas, J., dissenting). Though such institutional values might be justified as instrumental to the goal of efficient service, they need not have that effect and may instead become ends in themselves. Hence, the very foundation on which the constitutional limitation of public employees' rights rests may be infirm.

45. Pickering v. Board of Educ., 391 U.S. 563, 569-73 (1968). The first consideration involves the nature of the speech. The relevant factors include whether the speech is defamatory or false; whether the speech relates to a matter of public interest; whether the speech can be verified or refuted by the public record, or depends on the employee's special access to information; and whether the forum involved is appropriate. Id.

The second consideration involves the actual or potential impact of the speech on the employment relationship and on the efficiency of the public service. The relevant factors include whether the speech was directed at someone with whom the speaker maintained a close working relationship, such as an immediate superior; whether the speech might disrupt discipline or harmony among coworkers; and whether the job is by its nature especially sensitive to differences of opinion. Id. Given these factors, and their flexible judicial application depending on the nature of the public employment involved, see note 43 supra, the government may curtail employee conduct that genuinely threatens the efficient operation of public agencies.

46. In Mathews v. Eldridge, 424 U.S. 319 (1976), the Court, in determining that a particular administrative procedure was fair and reliable, pointed out that the medical inquiry at issue was sharply focused and easily documented and did not involve critical questions of witness credibility and veracity. $I d$. at 343-44. But removal of an employee is typically not a sharply focused inquiry, is not easily documented, and turns importantly on issues of witness credibility and veracity. Hence, errors are likely to be "numerous" in the absence of procedural safeguards. See Bishop v. Wood, 426 U.S. 341, 349.50 (1976). Although the Court does not condone constitutionally illicit motives in the employment context, the dearth of procedural safeguards in this context clearly increases the probability of their occurrence. 
discretionary administrative process on the already qualified First Amendment rights of public employees; hence, it fails adequately to vindicate those substantive rights.

\section{Rejecting the Current But-For Test}

\section{In Mt. Healthy City School District Board of Education v. Doyle, ${ }^{47}$} the Supreme Court, in a unanimous opinion, propounded a but-for test $^{48}$ for determining whether a public employee has been removed improperly from his job and is therefore entitled to reinstatement. ${ }^{49}$ In Mt. Healthy, a school teacher was not rehired at least in substantial part because he had informed a radio station that the school board had urged the teachers to adopt a dress code. ${ }^{50}$

The test developed by the Court in $M t$. Healthy involves two steps. First, a public employee who sues for reinstatement because of improper removal must demonstrate that an impermissible ground was a substantial or motivating factor in his removal. ${ }^{51}$ If the employee succeeds, then the burden shifts to the employer in the second step to show that he would have removed the employee even had the employee

47. . 429 U.S. 274 (1977).

48. In Mt. Healthy, the Court did not use the term "but for," but referred more generally to a "rule of causation" and "a test of causation." Id. at 285-86. The Court first used the phrase "but for" with respect to the test in Givhan v. Western Line Consol. School Dist., 439 U.S. 410,417 (1979).

49. Prior to $M t$. Healthy, lower courts differed as to the role impermissible motives had to play in a removal decision in order to justify reinstatement. Compare Simard v. Board of Educ., 473 F.2d 988, 995 (2d Cir. 1973) (test is "motivated only in part" by impermissible reasons) with Franklin v. Atkins, 409 F. Supp. 439, 446 (D. Colo. 1976), aff'd, 562 F.2d 1188 (10th Cir. 1977), cert. denied, 435 U.S. 994 (1978) (test is whether impermissible considerations were "paramount reason"). In Mt. Healthy itself, the District Court had found for the employee on the ground that a "non-permissible reason did play a substantial part" in the termination decision. Mt. Healthy City School Dist. Bd. of Educ. v. Doyle, 429 U.S. 274, 284 (1977) (emphasis added) (quoting lower court opinion).

50. The school superintendent informed the teacher that his contract had not been renewed because of the teacher's "notable lack of tact in handling professional matters which leaves much doubt as to your sincerity in establishing good school relationships." 429 U.S. at 283 n.1. The superintendent adduced two incidents as evidence: the teacher's phone call to a local radio station informing it of a professional dress code that the school board had suggested the teachers adopt, and the teacher's use of an obscene gesture to correct students in the cafeteria. The District Court found that the phone call was protected by the First Amendment and that it formed a substantial part of the school board's decision not to renew; hence, it ordered the teacher reinstated. Id. at 284. The Sixth Circuit affirmed. 529 F.2d 524 (6th Cir. 1975). The Supreme Court accepted the findings of the District Court but remanded the case with the instruction that the employer have the opportunity to show that regardless of the part played by the teacher's First Amendment activity in its decision not to renew, the board would have removed the employee even if he had not engaged in protected activity. 429 U.S. at 287.

51. 429 U.S. at 287. 
not engaged in the protected activity. ${ }^{52}$ The employee can prevail only if the court finds that he would have been rehired but for the impermissible factor. ${ }^{53}$

\section{A. The Policies Underlying Mt. Healthy}

The Mt. Healthy Court justified the but-for test in claims of improper dismissal with a cursory analysis of the competing interests at stake in public employment decisions. The Court contended that the test was necessary to prevent plaintiff windfalls, ${ }^{54}$ and buttressed that justification by drawing an analogy to the removal of unconstitutional taint in criminal proceedings. 55

\section{The Criminal Procedure Analogy}

The Court drew support for the but-for test from criminal procedure cases establishing that unconstitutional taint has a limited life. In those cases, the Court had held that an unconstitutional governmental act did not necessarily affect a subsequent event in the criminal process in such a manner that conviction had to be overturned. ${ }^{56}$ This analogy

52. Id. Variation in the standard of proof remains even among courts citing Mt. Healthy. Compare Mack v. Cape Elizabeth School Bd., 553 F.2d 720, 722 (1st Cir. 1977) (plaintiff bears burden of showing that but for impermissible factors, she would have been reemployed) and Tanner v. McCall, 441 F. Supp. 503, 513 (M.D. Fla. 1977) (plaintiffs must show impermissible reason was "primary and dominant cause" of terminations) with Ruhlman v. Hankinson, 461 F. Supp. 145, 150 (W.D. Pa. 1978) (jury properly instructed to find for plaintiff if impermissible reason was "substantial factor" in removal). It is unclear whether some courts have interpreted the Mt. Healthy "would-have" test as a more pro-defendant "could-have" test. In Morris v. City of Kokomo, 381 N.E.2d 510 (Ind. App. 1978), the court held that defendants may escape liability if they "prove ... that the decision to demote the plaintiffs was justified by reasons independent of the constitutionally protected conduct." Id. at 517. Mt. Healthy requires not merely that justifying reasons exist ("could have") but that defendants show they would have acted on such reasons absent plaintiff's First Amendment activity.

53. Givhan v. Western Line Consol. School Dist., 439 U.S. 410, 417 (1979). In Givhan the Court remanded the case because, "while the District Court found that petitioner's 'criticism' was the 'primary' reason for the School District's failure to rehire her, it did not find that she would have been rehired but for her criticism." Id. (emphasis in original).

54. 429 U.S. at 286 ("borderline or marginal [employee] .... ought not to be able, by engaging in such [protected] conduct, to prevent his employer from assessing his performance record and reaching a decision not to rehire on the basis of that record").

55. Id. at 286-87.

56. Id. In criminal law, even a serious infringement of a defendant's constitutional rights need not preclude conviction. If the government can show that the evidence on which conviction rested was untainted by the government's unconstitutional acts, the conviction will be upheld. See Nardone v. United States, 308 U.S. 338, 341 (1939). Mt. Healthy cited three criminal cases: Parker v. North Carolina, 397 U.S. 790, 796 (1970) (involuntariness of confession does not signify that subsequent guilty plea is involuntary); Wong Sun v. United States, 371 U.S. 471, 491 (1963) (statement given several days after unlawful arrest need not be found involuntary); Lyons v. Oklahoma, 322 U.S. 596, 603 (1944) (coercion of initial confession does not preclude subsequent confession from being voluntary). 
fails to recognize a crucial characteristic of the criminal procedure cases: the presence of two discrete, actual events. For there to be a proper analogy between $M t$. Healthy and the criminal procedure decisions, the latter would have had to suggest that a conviction based on an unconstitutional event, such as a coerced confession, would be upheld on a showing by the prosecution that it would have produced untainted evidence had it not rested its case on the involuntary confession. ${ }^{57}$ Rather than applying such reasoning, the Court in those cases held that the unconstitutional taint had been purged by the occurrence of a second event, such as a voluntary confession or a guilty plea. Moreover, the defendant was the moving force in the second, purgative event. $^{58}$ In the criminal cases, the Court validated the criminal process only after the process had worked properly on the second occasion. Mt. Healthy, however, allows the employer an opportunity to justify a decision post hoc and thus does not require that the administrative process ever work properly.

\section{The Danger of Plaintiff Windfalls}

The Mt. Healthy Court also contended that the but-for test was necessary to prevent plaintiff windfalls. ${ }^{59}$ Any weaker test for judging the permissibility of employer action, the Court said, "could place an employee in a better position as a result of the exercise of constitutionally protected conduct than he would have occupied had he done

57. The proof required in $M t$. Healthy contrasts sharply with that required to show the absence of unconstitutional taint in the criminal cases relied upon by the Court. In Nardone v. United States, 308 U.S. 338 (1939), the Court held that once a defendant proved that the government acquired evidence unlawfully and that "a substantial portion of the case against him was a fruit of the poisonous tree," the government must show that "its proof had an independent origin." Id. at 341. Under Mt. Healthy, the employer need not show that the removal had a basis independent of the employee's exercise of his speech rights, but merely that a hypothetical decision would have had such an independent basis-even though the actual decision was admittedly based substantially on an impermissible factor. 429 U.S. at 287; see Givhan v. Western Line Consol. School Dist., 439 U.S. 410, 417 (1979) (directing lower court to apply Mt. Healthy even though it found impermissible reason was primary factor in removal decision).

58. The appropriate criminal procedure analogy is not to the doctrine of unconstitutional taint, but rather to the harmless-error doctrine. Under the doctrine of unconstitutional taint, the evidence received by the jury is not tainted despite the prior commission of illegal acts by the government, so long as none of the information was obtained directly or derivatively from those acts. The harmless-error doctrine provides that even though the decisionmaker did receive illegal evidence or instructions, the conviction will not be disturbed if that information did not play a substantial role in the decision.

In $M t$. Healthy situations, once the plaintiff has shown that the decisionmaking involved illicit factors, the doctrine of unconstitutional taint is inapplicable. Moreover, the decision cannot be upheld as harmless error because the employee already has shown that the illicit consideration was a substantial factor in the decision.

59. 429 U.S. at 285-86. 
nothing." ${ }^{\circ 0}$ Although the potential for plaintiff windfalls would indeed be greater under a substantial-cause test, the Court exaggerated the remedial problems involved in reinstatement cases and failed to weigh the countervailing interests of ensuring administrative accountability and of preventing a chilling effect on other employees' speech.

The Court focused the windfall discussion on the "long-term consequences of an award of tenure." ${ }^{11}$ Tenure, of course, is an extreme example of the windfall problem; other employment remedies entail far less permanent consequences. Even tenure, however, does not involve the long-term consequences typical of true windfalls. Unlike the paradigmatic windfall-an excessive monetary award for personal injuries ${ }^{62}-$ the award in reinstatement cases is limited in extent and is not permanent. ${ }^{63}$ Other kinds of specific performance can be far more momentous than a judicial grant of tenure. ${ }^{6 t}$

By the Court's reasoning, moreover, any award for violation of rights could be deemed a windfall. Yet such awards usually are permitted without any requirement comparable to the Mt. Healthy test: convictions are overturned because of constitutional violations even though the defendant is guilty ${ }^{65}$ and bargaining orders are issued because of unfair labor practices even though the union would have lost

60. Id. at 285 .

61. Id. at 286 .

62. See F. James \& G. Hazard, Civil Proceddre $§ 7.21$, at 322,325 (2d ed. 1977) (recognizing jury's wide discretion in setting damages for personal injuries).

63. A tenured or nonprobationary employee is not irremovable; he is simply entitled to procedural rights and a showing of just cause for his removal. See notes $16 \& 17$ supra.

64. The Court has not refused to vindicate constitutional rights because of the longterm consequences of specific performance remedies. See, e.g., Keyes v. School Dist. No. 1, 413 U.S. 189 (1973) (permitting court orders for districtwide remedies to rest on findings of intentional discrimination in only part of the district); Reynolds v. Sims, 377 U.S. 533 (1964) (upholding court-ordered legislative reapportionment). When the costs of granting specific performance are great, however, the Court has been unwilling to order such a remedy if there were valid grounds for the action. For example, in Village of Arlington Heights v. Metropolitan Hous. Dev. Corp., 429 U.S. 252 (1977), decided the same day as Mt. Healthy, the Court noted that had the plaintiffs demonstrated that racial discrimination was a substantial factor in the village's decision not to rezone a certain area, the village would have been entitled to a $M t$. Healthy rebuttal, that is, a chance to show that it would have reached the same decision for legitimate reasons. Id. at 270-71 n.21. The long-term consequences of rezoning are much more permanent, and entail a much greater dislocation, than granting tenure to a single employee. Thus, although potential windfalls exist in establishing a higher threshold for dismissal of public employees, the cost to the government is not so great that it should entirely escape liability for a substantial infringement of a constitutional right.

65. See, e.g., Haynes v. Washington, 373 U.S. 503 (1963) (reversing conviction even though involuntary confession was completely unnecessary); Bollenbach v. United States, 326 U.S. 607 (1946) (reversing conviction because jury instruction contained unconstitutional presumption, even though evidence was ample to sustain verdict without presumption). 
the election anyway. ${ }^{66}$ The purpose of such awards is not simply to compensate the particular victim, but also to deter other abuses of the constitutional or statutory right. ${ }^{67}$ The same reasoning should apply to unconstitutional removals from public employment.

The Mt. Healthy Court also feared that an employee who suspected that he would not be rehired or granted tenure might engage in contentious speech in hopes of provoking the employer to remove him on that ground. ${ }^{88}$ That concern fails to recognize that protected speech does not lose that protection simply because of the speaker's motives. ${ }^{69}$ If the speech is protected, the employer is not permitted to remove the employee no matter how much the speech may annoy him. ${ }^{70}$ The but-for test thus cannot be justified on the basis of preventing plaintiff windfalls.

\section{B. The Defects of But-For Causation}

The but-for test of Mt. Healthy is inherently inappropriate in the employee-removal context. The term "but-for" can have either of two meanings. A but-for cause can be one that was a necessary component of the particular injurious event. It also can signify the absence of an

66. See NLRB v. Gissel Packing Co., Inc., 395 U.S. 575, 614-15 (1969) (bargaining order proper remedy for unfair labor practices that made fair election unlikely); Seeler $v$. Trading Port, Inc., 517 F.2d 33, 40 (2d Cir. 1975) (interim bargaining ordered even though union lost election 25 to 3 ).

67. The Court confronted the countervailing interests of avoiding windfalls and insisting on governmental integrity when it extended the exclusionary rule to state criminal proceedings. Mapp v. Ohio, 367 U.S. 643 (1961). The Court recognized the objection, voiced by Judge Cardozo, that "[t]he criminal is to go free because the constable has blundered." Id. at 659 (quoting People v. Defore, 242 N.Y. 13, 21, 150 N.E. 585, 587 (1926)). The Court's reply to Judge Cardozo effectively answers its fears in Mt. Healthy: "The criminal goes free, if he must, but it is the law that sets him free. Nothing can destroy a government more quickly than its failure to observe its own laws, or worse, its disregard of the charter of its own existence." 367 U.S. at 659 .

68. 429 U.S. at 286.

69. Weiss v. Willow Tree Civic Ass'n, 467 F. Supp. 803, 817 (S.D.N.Y. 1979) (“The protection of the First Amendment does not depend on 'motivation' "); cf. First Nat'l Bank of Boston v. Bellotti, 435 U.S. 765, 777 (1978) ("The inherent worth of the speech in terms of its capacity for informing the public does not depend upon the identity of the source, whether corporation, association, union or individual."). Motive is a consideration in determining whether an employee's speech is libelous and hence unprotected under the Pickering analysis. Pickering v. Board of Educ., 391 U.S. 563, 573.74 (1968). If the speech passes Pickering, motive should not reenter as a basis for not vindicating the exercise of a First Amendment right.

70. The Pickering test will already have taken into account disruption of the employment relationship. See note 45 supra. Moreover, disruption may not always be a sufficient ground for denying First Amendment protection to employee speech. See Porter v. Califano, 592 F.2d 770, 773-74 (5th Cir. 1979) (discounting disruption caused by employee's exposure of corruption within her department). 
alternative cause for the plaintiff's injury. ${ }^{71}$ Although the Court used the term in the latter sense, ${ }^{72}$ commentators have read both types of but-for causation into the $M t$. Healthy test. ${ }^{73}$

\section{But-For as the Absence of an Alternative Cause}

The Court's use of but-for to signify the absence of an alternative cause for the removal is less defensible than the interpretation of butfor as signifying a necessary component. Courts and commentators have discussed alternative causation in two general contexts: (1) where there is an independent cause operating prior to, ${ }^{74}$ simultaneously with, ${ }^{75}$ or subsequent $t^{76}$ the cause in question that would have injured the plaintiff even without the litigated cause; and (2) where the defendant has breached his duty to the plaintiff, yet the defendant's conduct would have injured the plaintiff (or would have failed to

71. The following example illustrates the distinction in the removal context. An employer has a strict rule of "three strikes and you're out." He counts an employee's protected activity as a strike against him; the employee already had two strikes and is fired. The employee's protected activity is thus a necessary component in the cause that brought about his removal. Immediately after the employer's decision, the mayor decides that no nontenured employees will be renewed because of budget problems. Thus, consideration of the employee's protected activity is not the only way in which the result at issue-his removal-could have been effected; it would have occurred regardless of the protected activity being counted against him. Consideration of the employee's protected conduct is therefore a but-for cause (a necessary component) yet is not a but-for cause (no alternative cause). See generally H. HART \& A. HonORE, Causation In the LAw 225-29 (1959) (discussing doctrine of alternative cause and its comparative law analogues).

72. See Mt. Healthy City School Dist. Bd. of Educ. v. Doyle, 429 U.S. 274, 285 (1977) (rejecting "rule of causation which focuses solely on whether protected conduct played a part, 'substantial' or otherwise, in a decision not to rehire" in favor of rule denying reinstatement if employer "would have reached [the same] decision had not the constitutionally protected incident" occurred) (emphasis in original).

73. Compare Van Alstyne, supra note 8, at $450 \mathrm{n.13}$ (test is one of alternative cause) with DuRoss, Toward Rationality in Discriminatory Discharge Cases: The Impact of Mt. Healthy Board of Education v. Doyle upon the NLRA, 66 Geo. L.J. 1109, 1113 (1978) (test is one of necessary component).

74. E.g., Pieczonka v. Pullman Co., 89 F.2d 353 (2d Cir. 1937) (decedent's silicosis existed prior to wrongful exposure to industrial dust); Dillon v. Twin State Gas \& Elec. Co., 85 N.H. 449, 163 A. 111 (1932) (decedent electrocuted by wires while falling from bridge).

75. Compare Cook v. Minneapolis, St. P. \& S. Ste. M. Ry., 98 Wis. 624, 74 N.W. 561 (1898) (no liability where two fires-one wrongful in origin, other innocent-combine to destroy property) with Anderson v. Minneapolis, St. P. \& S. Ste. M. Ry., 146 Minn. 430, 179 N.W. 45 (1920) (opposite holding on same facts) and Restatement (SECOND) OF TORTs $\$ 432$, Comment d, Illustration 4 (1965) (approving Anderson result).

76. E.g., Douglas, Burt \& Buchanan Co. v. Texas \& Pac. Ry. Co., 150 La. 1038, 91 So. 503 (1922) (though unlawfully maintained bridge blocked barge, downstream bridge would have blocked passage anyway); Victorson v. Milwaukee \& Suburban Transp. Corp., 70 Wis. 2d 336, 234 N.W.2d 332 (1975) (disabling stroke after injuries induced by defendant). 
prevent or cure the injury) even if it had been proper. ${ }^{77}$ The second is not a true case of alternative causation, but rather a test of whether the defendant's breach was a necessary component in the injurious event. ${ }^{78}$ Despite uncertainty whether the existence of an alternative cause should absolve the defendant of all liability, ${ }^{79}$ even those cases that rule for the defendant do not support the alternative-cause argument propounded by the Mt. Healthy Court. The alternative causes recognized in such cases differ from the alternative cause in $M t$. Healthy with respect to the probability of the second cause occurring and the independence of the second cause.

In the alternative-cause cases, the occurrence of the second cause is virtually certain..$^{80}$ In $M t$. Healthy situations, on the other hand, the second administrative decision-removing the employee on permissible grounds-is entirely hypothetical. Even if the Mt. Healthy Court's view of the remedial question is proper, the law of torts does not permit recovery to be defeated by the assertion of speculative alternative causes. ${ }^{81}$

77. The typical case involves a vehicle that was exceeding the speed limit when it hit the plaintiff. The causation question is whether, even if he had not been speeding, the defendant would have injured the plaintiff-that is, whether the excessive speed was a necessary component in the injurious event. See, e.g., Underwood v. Fultz, 331 P.2d 375, 378 (Okla. 1958) (excessive speed not necessary component of automobile hitting child); Texas \& Pac. Ry. v. McCleery, 418 S.W.2d 494 (Tex. 1967) (train's excessive speed not necessary component). See generally Cole, Windfall and Probability: A Study of "Cause" in Negligence Law, 52 Calif. L. Rev. 459 (1964) (discussing "darting-out cases," in which children are hit by speeding cars). For other situations in which the question of necessary component is decided by means of putting a hypothetical case, see, e.g., New York Central R.R. Co. v. Grimstad, 264 F. 334, 335 (2d Cir. 1920) (negligent failure to equip barge with life preserver not necessary component in drowning); Cole v. Shell Petroleum Corp., 149 Kan. 25, 36-37, 86 P.2d 740, 747 (1939) (obstructions of watercourse not necessary component of flood-damaged crops).

78. Necessary component goes to the question of whether there was a sufficient causal relationship between the breach and the injury to give rise to liability. Alternative cause assumes a sufficient causal relationship between breach and injury and goes to the question of damages. See H. HART \& A. HoNore, supra note 71, at 228-29 (distinguishing "genuine cases of alternative causation from cases where the wrongful aspect of defendant's act is causally irrelevant").

79. Compare Douglas, Burt \& Buchanan Co. v. Texas \& Pac. Ry. Co., 150 La. 1038, 91 So. 503 (1922) (no liability for lost profits because downstream bridge would have blocked passage anyway) with Navigazione Libera Triestina Societa Anonima v. Newtown Creek Towing Co., 98 F.2d 694, 698 (2d Cir. 1938) (respondent fully liable for cost of painting ship bottom even though painting would have been necessary within one to four months).

80. See notes 74-76 supra; cf. Cohn, Note, 86 LAw Q. Rev. 449, 452 (1970) (in German courts, "reserve cause" can be used to diminish damage award "only if it is wholly certain that it would have been operative in any event").

81. See Mt. Healthy City School Dist. Bd. of Educ. v. Doyle, 429 U.S. 274, 285.86 (1977). The Court has stated elsewhere that 42 U.S.C. $\$ 1983$ (1976), under which public employees can sue for reinstatement, was intended to create "a species of tort liability" in favor of persons who are deprived of "rights, privileges, or immunities secured" to 
The second prerequisite for an alternative-cause defense is the independence of the second cause. In no case has a defendant been permitted to argue that had he not injured the plaintiff wrongfully, he would have injured him innocently. ${ }^{82}$ In $M t$. Healthy situations, however, it is precisely some other hypothetical act of his own that the defendant offers as the alternative cause. In order to prevent administrative caprice, the defendant should be estopped from making such a defense.

\section{But-For as a Necessary Component}

If the but-for test is rejected in the sense intended by the $M t$. Healthy Court, it should not be resurrected with the meaning of "necessary component." That construction of but-for is wholly inadequate. Analytically, but-for works as a universal affirmative test of causation but fails as a universal negative test. ${ }^{83}$ If plaintiff shows that defendant's breach was a but-for cause of his injury, plaintiff should win. ${ }^{84}$ If plaintiff cannot show that defendant's breach was a but-for cause, however, plaintiff should not necessarily lose. ${ }^{85}$ Commentators have thus preferred the term "substantial" to "but for." 88 Though

them by the Constitution. Imbler v. Pachtman, 424 U.S. 409, 417 (1976); see Carey v. Piphus, 435 U.S. 247, 254-57 (1978) (damage awards under $\$ 1983$ governed by principle of compensation). Some commentators have criticized deriving a remedial approach to $\$ 1983$ from the law of torts. See, e.g., Nahmod, Section $19 S 3$ and the "Background" of Tort Liability, 50 IND. L.J. 5, 10-11 (1974). Professor Yudof has argued that if a tort analogy is proper in $\$ 1983$ actions, it should be an analogy to remedies for "dignitary torts," which are not limited to pecuniary injury. Yudof, Liability for Constitutional Torts and the Risk-Averse Public School Official, 49 S. CaL. L. Rev. 1322, 1380 (1976). Even if monetary damages are governed by principles of tort liability, it does not follow that suits for reinstatement should be so analyzed. Traditionally, an equitable remedy-such as reinstatement-was proper precisely because the legal remedy was inadequate.

82. That claim is distinct from a defendant's argument that his breach was causally irrelevant. See notes 77-78 supra. A person who fails to take some preventive or curative measure is not liable if the independent, actively injurious force is so powerful that even the correct preventive or curative measures would have been of no avail. See, e.g., New York Central R.R. Co. v. Grimstad, 264 F. 334, 395 (2d Cir. 1920) (failure to provide life preservers as preventive measure); Kuhn v. Banker, 133 Ohio St. 304, 13 N.E.2d 242 (1938) (surgeon's failure to take proper curative measures). In those cases the defendant does not appea! to another act of his own as the active cause of the injury.

83. Carpenter, Concurrent Causation, 83 U. PA. L. Rev. 941,948 (1935).

84. This assumes, of course, that defendant's breach was sufficiently proximate.

85. If three men of equal strength push a car over a cliff, and the force of only two is necessary to accomplish the feat, each man can correctly claim that he is not a but-for cause of the car's damage. Carpenter, supra note 83, at 948.

86. See, e.g., L. Green, Rationale of Proximate Cause 180-85 (1927); W. Prosser, HANDBOOK OF TORTs 238-41 (4th ed. 1971); Carpenter, supra note 83, at 952 (preferring "material factor" to "but for"). Hart and Honoré deprecate the substantial factor test, however, because it is "vague" and because "the jury must rely on intuition to apply it." H. Hart \& A. Honore, supra note 71, at 263-68. Professor Green has responded that the 
"substantial" does not signify a level of importance noticeably lower than "but for," 87 it avoids pro-defendant speculation as to whether a significant or appreciable factor amounts to a necessary component.

\section{The In Terrorem Effect}

The most serious defect of the $M t$. Healthy test is that it exacerbates the chilling effect ${ }^{88}$ of reprisals on public employees exercising First Amendment rights. ${ }^{89}$ Although the notion of chilling effects was developed in the context of overbroad legislation, ${ }^{90}$ an administrative decision can create as objectionable a chilling effect as any statute. ${ }^{91}$

Indeed, several features of administrative action may make it even more chilling than a statute. ${ }^{92}$ An employee fearful of repressive ad-

test is no more vague or intuitive than the "reasonableness" standard, which is considered a proper term in which to couch jury questions. Green, The Causal Relation Issue in Negligence Law, 60 Mrch. L. Rev. 543, 554 (1962).

87. "Substantial" has been glossed in terms of "significant," W. Prosser, supra note 86 , at 240 n.29, and "appreciable," L. GREEN, supra note 86, at 185.

"Partial cause," or "even a partial cause," does signify a lower level of importance. In the analogous area of labor law, however, a number of circuits order reinstatement on this rather weak causal relation. See note 103 infra.

88. The phrase "chilling effect" is derived from Wieman v. Updegraff, 344 U.S. 183, 195 (1952) (Frankfurter, J., concurring).

89. The chill doctrine recognizes the tendency of individuals to steer clear of activity proscribed by the government. Even if the activity in which they wish to engage might fall outside the area clearly covered by the statute, or even if a statute that does cover the activity has gone unenforced, persons will tend to avoid that activity. NAACP v. Button, 371 U.S. 415, 433 (1963) ("The threat of sanctions may deter . . . almost as potently as the actual application of sanctions."). When the proposed activity is protected by the First Amendment, such avoidance has been held to be an unacceptable cost of governmental control and regulation. Id.

90. See, e.g., Aptheker v. Secretary of State, 378 U.S. 500 (1964) (invalidating law prohibiting member of Communist organization from using passport with "knowledge or notice" that registration order had become final); Shelton v. Tucker, 364 U.S. 479 (1960) (invalidating law requiring teacher to list every organization with which he was affiliated over five-year period). See generally G. GunTHER, CASES AND MATERIALS on Constitutional LAw 1132-42 (9th ed. 1975) (discussing attractiveness and curtailment of overbreadth technique); Note, The First Amendment Overbreadth Doctrine, 83 Harv. L. Rev. 844 (1970).

91. See, e.g., Keyishian v. Board of Regents, 385 U.S. 589, 601 (1967) (recognizing chilling effect of "intricate administrative machinery"); Adcock v. Board of Educ., 10 Cal. 3d 60, 66, 513 P.2d 900, 904, 109 Cal. Rptr. 676, 680 (1973) (en banc) (recognizing chilling effect of transfer).

The factors that inhibit violation of the unconstitutional features of an overbroad statute are present in the employment context: respect for authority, uncertainty as to whether the activity will be held protected, fear of government sanctions, and general unwillingness to bear the burden of litigation. See Note, supra note 90, at 854-55 (factors inhibiting challenge of overbroad statute).

92. A person who fears that an overbroad statute will be invoked against him knows that the government will have to take the initiative, specify the acts for which he is being prosecuted, and prove its case beyond a reasonable doubt. If he is convinced that the activity is protected by the First Amendment, the person can expect ultimate vindication despite the statutory prohibition. See T. Emerson, supra note 39, at 163 (administra- 
ministrative action confronts secrecy and uncertainty at all stages of employment. ${ }^{93}$ Even when an employee is entitled to due process protection, the requirements are rudimentary and administrative discretion is practically unconstrained. ${ }^{94}$ Moreover, the public employee labors under great uncertainty as to the scope of his First Amendment rights. ${ }^{95}$ The typical chill produced by an overbroad statute is thus aggravated in the administrative context by the higher degree of substantive uncertainty and the secrecy surrounding personnel decisions, as well as the difficulties of proving institutional motive, ${ }^{96}$ and the plaintiff's burden of going forward. ${ }^{97}$

When an employee challenges an allegedly impermissible dismissal, he protects not only his own rights but the rights of other employees as well. If the removed employee loses after carrying his burden of proof, then other employees-who on the Mt. Healthy Court's assumption are "marginal"98_-will be forced to calculate whether reprisals for their exercise of similar First Amendment rights would amount to a but-for cause of their removal. Because of uncertainty as to the future actions of an employer, these other employees may well adopt a cautious posture and not exercise their full First Amendment rights. The Court's adoption of the tort-law principle of limiting the remedy to the plaintiff's actual injury fails to recognize the plaintiff's representation of these other employees' First Amendment interests.

tive system may be "much tighter, more pervasive form of restriction" than criminal system). But see Babbitt v. United Farm Workers IJat'l Union, 99 S. Ct. 2301, 2319 n.6 (1979) (Brennan, J., dissenting) ("criminal sanctions discourage speech much more powerfully than do administrative regulations").

93. See Shelton v. Tucker, 364 U.S. 479, 486 (1960) (noting that school administrators “can terminate the teacher's employment without bringing charges, without notice, without a hearing, without affording an opportunity to explain"); T. EMERson, supra note 39 , at 163 ("low visibility" of administrative action results in "imagined impact of restriction" being "most repressive feature of all"). Compare NAACP v. Button, 371 U.S. 415 (1963) (association's bringing suits on behalf of black children despite statutory prohibition protected) with Abbott v. Thetford, 534 F.2d 1101 (5th Cir. 1976) (en banc), cert. denied, 430 U.S. 954 (1977) (probation officer's bringing suits on behalf of black children despite superior's prohibition unprotected).

94. See pp. 378-79 supra (employee's rudimentary procedural protection).

95. In contrast to ordinary citizens, who are encouraged to engage in robust, wideopen debate, see New York Times Co. v. Sullivan, 376 U.S. 254, 270 (1964), public employees are cautioned against disturbing the authority of supervisors or harmonious relations among fellow workers, see Pickering v. Board of Educ., 391 U.S. 563, 568.72 (1968). It is difficult for an employee to determine in advance whether his actions will so disturb the workplace that they will be unprotected.

96. See Note, Reading the Mind of the School Board: Segregative Intent and the De Facto/De Jure Distinction, 86 YALE L.J. 317, 322-26 (1976) (examining difficulties of determining institutional intent).

97. See Speiser v. Randall, 357 U.S. 513, 526 (1953) (recognizing chilling effect of bearing burden of proof on exercise of First Amendment rights).

98. Mt. Healthy City School Dist. Bd. of Educ. v. Doyle, 429 U.S. 274, 286 (1977). 
The Mt. Healthy test, then, should be rejected as ill-founded and unsound. The criminal procedure analogy simply collapses under scrutiny. The Court's concern with plaintiff windfalls is exaggerated. More important, the basic appeal to alternative causation is without logic or foundation in precedent. The test contravenes the policies of constraining governmental decisionmaking within constitutional bounds and of minimizing chilling effects on the exercise of First Amendment rights.

\section{The Substantial-Cause Test}

The Court should replace the but-for test with a simple substantialcause test. Under that test, the plaintiff would continue to bear the burden of proving that his exercise of First Amendment rights was a substantial or motivating factor in the employer's decision to remove him. If he carried that burden, however, the employee would win outright. The employer would have no opportunity to claim that although he actually removed the employee for impermissible reasons, the employee would have been removed even though he had not engaged in the protected activity. The standard of "substantial or motivating factor" would focus a court's attention on the actual decision to remove the employee, asking whether constitutionally improper considerations played a significant, important, or appreciable part in the decision. It would discourage pro-defendant speculation on conjectural alternative causes.

\section{A. Justifications for the Substantial-Cause Test}

Unlike the $M t$. Healthy test, the substantial-cause test would accord with the theory of causation that governs the law of torts. In tort law, a defendant is liable whenever his breach has been found to be a substantial, significant, or appreciable factor in causing the plaintiff's injury. ${ }^{90}$

Moreover, in public-employee reinstatement cases, two special factors urge that doubts about the importance of a defendant's breach be resolved in favor of the plaintiff. The first is the chilling effect that an

99. See notes $86-87$ supra. In rare cases, defendant's liability may be reduced if he can show the certain existence of an independent innocent cause whose certain or highly probable effect is injury to the plaintiff. See notes 74-76 supra. The alternatively caused injury depreciates the value of that interest of the plaintiff that the defendant has wrongfully injured. Such an anomalous situation will arise no more frequently in impermissible removal cases than it does in tort law generally. Mt. Healthy itself certainly did not present such a situation. 
administrative decision substantially motivated by a desire to penalize protected speech will have on other employees' exercise of First Amendment rights. ${ }^{100}$ The second is the tainting effect that an employer's hostility to the employee's protected activity can have on his consideration of other, legitimate factors. ${ }^{101}$ When the employee's protected speech has been a substantial factor in his removal, the likelihood that legitimate considerations have been tainted is far greater than if the protected speech was merely a partial cause in the administrative decision. ${ }^{102}$ As a less pro-defendant standard than the but-for test, substantial-cause is necessary to minimize chill and taint.

A substantial-cause theory also would conform to the case law governing the analogous area of discriminatory discharge under the National Labor Relations Act. Courts do not recognize a theory of alternative causation in labor law cases and some courts order reinstatement using only a partial-cause standard. ${ }^{103}$

Furthermore, a substantial-cause test would emphasize the constitutional bounds on discretionary administrative decisionmaking by focusing on the actual decision that infringed an employee's rights, instead of disregarding an unconstitutional decision on the basis of a conjectural event. Such a result-oriented constraint on governmental decisionmaking is required in an area in which procedural safeguards have been withheld in order to conserve fiscal and administrative resources. ${ }^{104}$ The more discretion that is granted decisionmakers, the less its abuse should be countenanced.

100. See pp. 391-92 supra (discussing chill).

101. It is more likely that conflicts will arise between an outspoken employee and his supervisors or coworkers; his deficiencies will appear more glaring to a superior watching with the eyes of an adversary.

102. The disruptiveness of the employee's speech has already been counted against him in the Pickering calculus, see note 45 supra, and resolved in his favor. It should not reenter the calculation as unrecognized taint.

103. In adjudicating labor law cases, only the First Circuit requires a but-for standard of proof before reinstating the employee. See Coletti's Furniture, Inc. v. NLRB, 550 F.2d 1292, 1293 (lst Cir. 1977) (after Mt. Healthy, NLRB must use First Circuit's "dominant motive" rule); DuRoss, supra note 73 , at $1112-13$ (Mt. Healthy supports adoption of First Circuit test in labor law). The other circuits require a substantial-factor or a partial-cause standard. See, e.g., Betts Baking Co. v. NLRB, 380 F.2d 199, 203 (10th Cir. 1967) (violation if union activity "but a partial motive"); NL.RB v. Symons Mfg. Co., 328 F.2d 835, 837 (7th Cir. 1964) (violation unless discharge "predicated solely" on valid ground); DuRoss, supra note 73 , at 1111-12 n.16 (collecting cases). There is no sound basis for contending that the protection given to the First Amendment should be weaker than that afforded statutory labor rights. The courts are to examine alleged violations of First Amendment rights with "closest scrutiny." See NAACP v. Alabama ex rel. Patterson, 357 U.S. 449, 460-61 (1958). But see Federal-Mogul Corp. v. NLRB, 566 F.2d 1245, 1265 (5th Cir. 1978) (Thornberry, J., concurring) (NLRA strikes legislative balance more favorable to employees than does Mt. Healthy test in First Amendment area).

104. See Mathews v. Eldridge, 424 U.S. 319, 347.48 (1976) (recognizing consideration of conserving fiscal and administrative resources). 
Justification of the substantial-cause test thus rests on its ability to minimize taint and chill, on its consistency with related areas of law, and on its emphasis on constitutional restraints for discretionary administrative decisionmaking.

\section{B. Shortcomings}

The substantial-cause test might be criticized from two directions: as going too far, and as not going far enough.

\section{Pro-Defendant Objections}

Those who believe that the test would go too far could lodge three principal objections: that judicial invalidation of governmental action on the basis of motivation is improper; that the substantial-cause test would aggravate employee goading of employers; and that the test would excessively involve federal courts in personnel decisions. ${ }^{105}$

The major problems with invalidating governmental action on the basis of motivation are ascertainability, futility, and disutility. ${ }^{106} \mathrm{Al}-$ though these objections may be powerful with respect to legislation, they do not present insurmountable difficulties with respect to administrative action. It usually will be impossible for a court to ascertain the motives of the scores, or even hundreds, of legislators who pass a piece of legislation. ${ }^{107}$ Even if this evidentiary obstacle is overcome, overturning such legislation may be futile because an identical statute could be passed with a purified legislative history. ${ }^{108}$ Furthermore, it may be unprofitable to strike down legislation that is "laudable in operational terms" simply because it was improperly motivated..$^{109}$

These concerns are less telling in reviewing administrative action.

105. All three of these objections also could be lodged against the "but-for" test. The specific objection against the substantial-cause test is that it aggravates each of these difficulties.

106. See Ely, Legislative and Administrative Motivation in Constitutional Law, 79 YALE L.J. 1205, 1212-17 (1970). Although these objections bear against the but-for test because it too is based on motivation, they bear more heavily against the substantial-cause test. As a more pro-defendant test, but-for may be viewed as a judicial response to the difficulties raised by ascertainability, futility, and disutility. The following analysis argues that in an administrative context these considerations are not so weighty that a but-for test is required.

107. See id. at 1285; A. Bickel, The Least Dangerous Branch 217 (1962).

108. See A. Bickel, supra note 107, at 216; Ely, supra note 106, at 1214-15. The courts cannot impose procedural requirements on the legislature, and the Congress, at least, is protected by the speech or debate clause from having its members explain their motives for legislative acts. U.S. CoNsT. art. I, $\$ 6, \mathrm{cl}$. I; see Note, Evidentiary Implications of the Speech or Debate Clause, 88 YALE L.J. 1280, 1286-87 n.30 (1979) (clause protects sensitive legislative compromises).

109. Ely, supra note 106, at 1215 . 
First, it is far easier to determine the motivation of a few administrators in a quasi-judicial action such as a personnel decision than to ascertain the motivation of perhaps hundreds of legislators. Second, it is proper for courts to impose mandatory procedures on administrative bodies whereas they can not impose procedural requirements on legislatures. If reinstatement appears to be a futile remedy because the employer will merely remove the employee a second time, the courts can demand that the initial burden be on the employer in the second removal to show by substantial evidence or by clear and convincing evidence that it has legitimate reasons for removing the employee. ${ }^{110}$ Finally, although there may be disutility in invalidating a governmental action that is "laudable in operational terms" because it was improperly motivated, the chilling effect on other employees' speech caused by an unconstitutionally motivated removal makes any utility calculus problematic.

The answer to the second objection, concerning employee goading, ${ }^{111}$ has already been suggested: an activity does not lose its constitutional protection because of the actor's motives. ${ }^{112}$ Extreme forms of goading by an employee will not pass the balancing test established by the Court in Pickering $v$. Board of Education; ${ }^{113}$ if the activity survives Pickering, an employer who has effected an unconstitutional removal should not be given a second chance. ${ }^{114}$

The third objection, that the substantial-cause test could injure federalism and aggravate the caseload of the federal courts, ${ }^{115}$ also fails:

110. See Brest, Palmer v. Thompson: An Approach to the Problem of Unconstitutional Legislative Motive, 1971 Sup. CT. REv. 95, 126 (suggesting that courts "enjoin an administrative decisionmaker from making the same decision again unless he comes forward with persuasive evidence that this time it will be made only for legitimate reasons").

111. Mt. Healthy City School Dist. Bd. of Educ. v. Doyle, 429 U.S. 274, 286 (1977); see p. 387 supra.

112. See p. 387 supra.

113. 391 U.S. 563, 568-72 (1968); see note 45 supra; cf. Givhan v. Western Line Consol. School Dist., 439 U.S. 410,415 (1979) (when "private expression" at stake, additional factors enter Pickering calculus).

114. The employer remains free after the reinstatement to make determinations of the employee's professional qualifications. See Ofsevit v. Trustees of Cal. State Univ. and Colleges, 21 Cal. 3d 763, 776 n.13, 582 P.2d 88, 95 n.13, 148 Cal. Rptr. 1, 8 n.13 (1978) (en banc) (reinstating university lecturer).

115. In Bishop v. Wood, 426 U.S. 341 (1976), the Court appealed both to federalism and to its high caseload to justify judicial restraint. With respect to caseload, the Court stated: "The federal court is not the appropriate forum in which to review the multitude of personnel decisions that are made daily by public agencies." Id. at 349 . The federalism point was more explicit: "the ultimate control of state personnel relationships is, and will remain, with the States; they may grant or withhold tenure at their unfettered discretion." Id. at 349-50 n.14. 
the states are not permitted to evade the First Amendment by invoking federalism. ${ }^{116}$ Moreover, local autonomy is fostered by the weaker substantive constraints and the minimal procedural constraints placed on government as an employer. ${ }^{117}$ Overload of the federal courts should be dealt with by means other than discouraging the vindication of constitutional rights.

\section{Pro-Plaintiff Objections}

Those who believe that the substantial-cause test would not go far enough might argue that a focus on the actual decision would simply encourage employers to be more devious in removing outspoken employees. That danger may be exaggerated because the employer would have to have some legitimate reason for removal. An employer would have difficulty contriving such a reason where his disfavor with the employee arose shortly after the employee's exercise of protected speech.

If employer deception were to become a serious impediment to application of the substantial-cause test, one solution might be to require the employer to provide even nontenured or probationary employees with reasons for their removal.118 Although that requirement would not preclude an employer from giving false reasons, ${ }^{119}$ the employee would have a better indication whether the employer's reasons were plausible. The existence of such a concrete explanation would facilitate rebuttal by employees who believed that the reasons were spurious. Moreover, it would be a small step to require a statement of reasons at the time of removal because the employer already is required to provide reasons after an employee sues for reinstatement. Such a requirement would not diminish the immense range of legitimate reasons for which

116. See Fiske v. Kansas, 274 U.S. 380, 387 (1927) (First Amendment applies to states through Fourteenth); Gitlow v. New York, 268 U.S. 652, 666 (1925) (same). No more than a small minority of the Supreme Court has ever maintained that First Amendment protection is to any degree diminished in passing to the states through the medium of the Fourteenth Amendment. For the minority view, see Buckley v. Valeo, 424 U.S. 1, 291 (Rehnquist, J., concurring); Beauharnais v. Illinois, 343 U.S. 250, 287-95 (1952) (Jackson, J., dissenting).

117. See pp. 378-82 supra.

118. See Board of Regents v. Roth, 408 U.S. 564, 589 (1972) (Marshall, J., dissenting) (statement of reasons should be required when public employment not renewed); $K$. Duvis, supra note 4, at 103-06 (written reasons and findings especially important in discretionary determinations).

119. See K. DAvis, supra note 4, at 106 (difficult to prevent substitution of "readymade boiler plate" for statement of motivating reasons, but "nearly all administrators most of the time take the requirement [of reasons and findings] seriously"). 
an employer may remove an employee, nor would its fiscal or administrative burden be significant. ${ }^{120}$

Thus without unacceptably constricting administrative discretion, the substantial-cause test would reduce its constitutionally impermissible costs. Such a test for determining the permissibility of government personnel decisions is superior to the current Mt. Healthy but-for test because it weighs the constitutional values at stake in removals more sensitively and perceives more realistically the balance of power between government employers and employees.

120. See Board of Regents v. Roth, 408 U.S. 564, 591 (1972) (Marshall, J., dissenting) ("not burdensome to give reasons when reasons exist"); K. DAvis, supra note 4, at 104-05 (use of written reasons by Immigration Service, though initially considered impractical, required no increase in staff). 